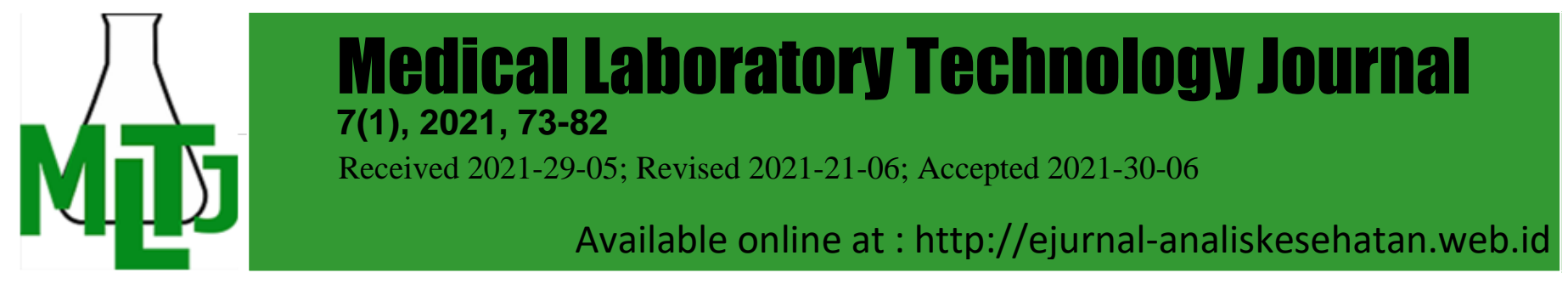

\title{
Comparison of Clinical Assessment and Adhesive-Tape Laboratory Microscopic of Sarcoptes scabiei for Scabies Diagnostic
}

\author{
${ }^{\star}$ Rifqoh, Wahdah Norsiah, Neni Oktiyani \\ Medical Laboratory Technology Poltekkes Kemenkes Banjarmasin \\ Mistar Cokrokusumo Street 4A Banjarbaru Indonesia \\ *Email: rif.mayasin@gmail.com \\ DOI: 10.31964/mltj.v7i1.379
}

\begin{abstract}
Scabies infestation caused by Sarcoptes scabiei mite that infected the skin by making the tunnel burrow. Diagnosis of scabies infestation commonly relies on clinical assessment (CA). However, some scabies symptoms are similar to other diseases. Diagnosis of confirmed scabies can be made by identifying egg or Sarcoptes scabiei mite or scybala through skin scraping laboratory microscopic examination, which was the adhesive tape microscopic (AT) a noninvasive alternative. We aimed to compare the scabies diagnostic accuracy of CA and AT in Islamic Boarding School. This study was an analytical observational cross-sectional study. The population was 94 students of Islamic Boarding School, determining the sample base on purposive sampling technique. There were 34 samples with presumptive scabies analyzed with CA by two clinicians and AT by two trained laboratory technicians. The result showed that the number of patients who positive scabies by CA was 14 (41.18 percent) and 31 (91.18 percent) by AT. Sensitivity was 41.93 percent for CA and 92.85 percent for AT, and the difference was significantly based on Cohen's kappa ( $k=0.024)$. The number of positive cases with both techniques was 13 (38.24 percent). The number of patients positive with only CA was 1 (2.93 percent), and only AT was 18 (22.9 percent). The accuracy of CA was only 44,11 percent. The study concluded that CA is low accuracy than AT. The adhesive tape test is easy, needs no expensive equipment. It is recommended that adhesive tape test for screening purposes. The appropriate comprehensive of both methods for scabies diagnostic is highly recommended.
\end{abstract}

Keywords: Scabies; clinical assessment, adhesive-tape; Sarcoptes scabiei

\section{INTRODUCTION}

Scabies Infestation is a contagious skin disease caused by Sarcoptes scabiei var hominis, a human-specific mite with a size of approximately $0.4 \mathrm{~mm}$ that is invisible to the naked eye. This ectoparasite infests on human skin that causes itching, pruritus, and rash, resulting may cause stigma, which can lead to sleep disruption, difficulty with a concentration in the patients. It commonly infected the palm, legs, and skin folds such as armpits, areola, groin, and genital areas. This disease can be transmitted directly, e.g., shake hands, sleep together, and through sexual relations. Transmission indirectly, for example, through clothes, towels, bedsheets, pillows, and blankets (Engelman et al., 2020); (Walter et al., 2011)

Scabies remained a significant public health problem concern and estimated to affect more than 200 million people globally. Scabies affecting people of all ages, races, and socioeconomics groups, but with a higher burden in low-income settings and tropical areas, especially in children, adolescents, and older people. (Zhang et al., 2020) 
Scabies infests people who lived in a group, such as in orphanages, refugees, army barrack, prisons, dormitories. In Indonesia, scabies commonly infests students in dormitories of Islamic Boarding School. Many factors were associated with scabies incidence in Indonesian Islamic Boarding school, including environmental factors, especially occupation density and individual or community hygiene factor in dormitories. Scabies in humans is still ignored by the community, mainly student living in Islamic boarding school, because of a lack of knowledge about the causes, transmission, prevention, and complication of scabies. (Trasia, 2021)

A definitive diagnosis for scabies is essential. Although it causes skin disease, scabies is frequently complicated with secondary infection by bacteria Streptococcus pyogenes, and Staphylococcus aureus cause impetigo may result in abscesses. It can cause life-threatening diseases, including sepsis and glomerulonephritis. (WHO, 2019). Diagnosis of scabies infestation commonly relies upon clinical assessment. However, some of the scabies symptoms are similar to other diseases, such as pyoderma and atopic dermatitis, especially in children and immunocompromised conditions. (Walker et al., 2020).

The diagnosis of confirmed scabiei can be made by identifying egg or Sarcoptes scabiei mite or scybala through skin scraping microscopic laboratory examination, but it is invasive. The adhesive tape laboratory microscopic is a noninvasive alternative (Walter et al., 2011). The previous study by (Audhah et al., 2012) in Darul Hijrah Islamic Boarding School used adhesive tape to confirm the diagnosis of scabies. However, this method is used for its research purposes only. Scabies diagnostic in Islamic Boarding School Kalimantan Selatan, Indonesia still passive which student with itchy and chronic lesion will check to the public health facilities (Muafidah et al., 2017).

The diagnosis of scabies in Indonesia based on clinical practice guidelines for doctors in primary health facilities Permenkes RI No.5 2014 confirmed if it shows two from 4 cardinal signs and skin scraping microscopic laboratory examination supporting the diagnosis. Skin scraping is not done because it is invasive. Therefore the diagnosis of scabies is confirmed by clinical assessment only. The resulting study by (Leung \& Miller 2011) shows that clinical assessment and history of itch only failed to diagnose scabies accurately. It needs another diagnostic test with reference standard with microscopic visualization to confirmed mite or egg existence. This study compares the scabies diagnostic accuracy of clinical assessment (CA) and adhesive tape microscopic examination (AT) in Islamic Boarding School.

\section{MATERIALS AND METHOD}

This study was an analytical observational with a cross-sectional approach that compares clinical assessment (CA) by two clinicians in Martapura Barat Public Health Centre and the result of the Adhesive-Tape laboratory microscopic examination (AT) by two trained laboratory technicians. The population used in this study were 94 male students of one Islamic Boarding School in the Martapura Barat Public Health Centre Area. Determination of sample based on purposive sampling technique. Sample inclusion criteria were the patient's presumptive determination of scabies, boarding dormitories, the patient complained of nocturnal pruritus for more than one week, and lesions. Sample exclusion criteria were no lesions, ever given topical scabicide treatment $\leq$ two weeks before sampling. The number of samples that met the inclusion criteria was 34 samples. 
This study was conducted from April $29^{\text {th }}$ to May $20^{\text {th }}, 2017$, at Pondok Pesantren Al Hidayah in Martapura Barat Public Health Centre for Clinical Assessment and Adhesive-Tape sampling preparation. Identification of eggs, immature and adult Sarcoptes scabiei mite presence used light microscope in Parasitology Laboratorium at Poltekkes Kemenkes Banjarmasin.

The instrument used in this study was a clinical assessment by two clinicians of Martapura Barat Public Health Centre using physical examination and clinical assessment form. The clinical assessment for scabies suspected if a patient showed a suspicious skin alteration accompanied by itching, especially at night (nocturnal pruritus) for at least one week, presence of a characteristic primary lesion (papules, vesicles, or nodules) in the thin stratum corneum, such as between the fingers, wrist, and feet, axillae, umbilicus, mammae areola and under the breast (in women) and the genitalia externa (in men). Bacterial superinfection was diagnosed when pustules, suppuration, or an abscess.

The adhesive-tape laboratory microscopic examination by two trained laboratory technicians of Parasitology Laboratorium in Poltekkes Kemenkes Banjarmasin. The adhesive test was performed as described by (Katsumata \& Katsumata, 2006) using transparent adhesive tape (Tartan Tape; 3M Company, St Paul, Minnesota) was cut into strips of the size of a microscope slide (25 x $50 \mathrm{~mm})$ that is applied to a lesion firmly and then pulled off rapidly. The tape was transferred to slide, and it was stored in an icebox $\left(10^{\circ} \mathrm{C}\right.$ to $\left.14^{\circ} \mathrm{C}\right)$ until it was read. Slides were examined within the next 3 hours. Slides were scanned used Olympus CX33 trinocular microscope at 100x magnification. If an egg or mite was suspected, the magnification was increased to 400x magnification. The presence of eggs, immature and adult mite Sarcoptes scabiei, or scybala was reported as positive scabies (Engelman et al., 2020); (Walter et al., 2011).

Data collected and edits to make to check completeness, continuity, and validation data. Data entered into a computer program, data analysis obtained in primary data, namely clinical assessment result and adhesive-tape microscopic result. Statical analysis used Cohen's Kappa and computed the diagnostic parameter test: positive predictive value, negative predictive value, sensitivity, specificity, and accuracy.

This study was approved by Health Research Ethics Committee Poltekkes Kemenkes Banjarmasin (HREC-PKB) No. 064/KEPK/2017. Informed consent was obtained from each patient after explaining the objective study for patients under 18 years old, signed by their parents.

\section{RESULTS AND DISCUSSION}

Table 1. Characteristic Patients

\begin{tabular}{cr}
\hline Characteristic & Positive \\
\cline { 2 - 2 } & $\mathrm{N}(\%)$ \\
\hline Sex: Male & $34(100)$ \\
Female & $0(0)$ \\
Age: $12-17$ years old & $16(47.06)$ \\
$18-19$ years old & $18(52.94)$ \\
\hline
\end{tabular}


Table 2. Lesions Identification

\begin{tabular}{lrr}
\hline \multicolumn{1}{c}{$\begin{array}{c}\text { Lesions } \\
\text { Identification }\end{array}$} & Positive & Negative \\
\cline { 2 - 3 } $\begin{array}{l}\text { Duration of the lesion } \\
\text { (week) }\end{array}$ & $\mathrm{N}(\%)$ & $\mathrm{N}(\%)$ \\
$\leq 3$ & $2(5.88)$ & $3(8.82)$ \\
$4-8$ & $0(0)$ & $2(5.88)$ \\
$>8$ & $12(35.29)$ & $15(44.12)$ \\
Type of lesion* & & \\
Papules & $13(38.23)$ & $0(0)$ \\
Burrow & $6(17.65)$ & $0(0)$ \\
Vesicules & $6(17.65)$ & $0(0)$ \\
Nodules & $6(17.65)$ & $0(0)$ \\
Excoriation & $0(0)$ & $5(14.71)$ \\
Crusted & $6(17.65)$ & $1(2.94)$ \\
Suppuration & $0(0)$ & $2(5.88)$ \\
Erythema & $9(26.70)$ & $7(20.59)$ \\
Pustule & $0(0)$ & $5(14.71)$ \\
Abscess & $0(0)$ & $4(11.76)$ \\
\hline Clinical scabies & $14(41.17)$ & $20(58.82)$ \\
\hline *multiple classifications were possible &
\end{tabular}

Table 1 shows characteristics (sex and age) base on identity formation. All 34 (100 percent) patients were male, 16 (47.06 percent) patients were teenagers, and 18 (52.94 percent) were early adult ages. Only male students live in Al Hidayah Islamic Boarding School dormitories.

Table 2 shows lesions identification (duration and type) of patients based on physical examination and clinical assessment, 14 (41.17 percent) patients diagnosed positive, and 20 (58.82 percent) patients diagnosed with negative scabies. Diagnosis for scabies by clinical assessment requires considerable training and frequent experiences, however visually assessment was inappropriate to assessing the structure depicted in the lessions base on clinical knowledge only, especially to scabies with secondary infection, because the symptoms of diseases often are masked and can similar to other diseases symptoms(Zorbozan et al., 2020).

Patients diagnosed clinically positive scabies with the duration of lesions $<3$ weeks were two patients (5.58 percent) and 12 patients (35.29 percent) with the duration of lesions > eight weeks. There were 20 patients (58.82 percent) diagnosed with negative scabies with the duration of lesions $<3$ weeks three patients $(8.82$ percent), with the duration of lesions 4-8 weeks were 2 (5.58 percent) patients and 15 (44.12 percent) patients with duration of lesions $>8$ weeks. Early infestations are usually asymptomatic for a 4-6 weeks incubation period. Symptoms develop much more rapidly (hours to days) with subsequent infestations. The female Sarcoptes scabiei lays eggs and larvae hatched, later become nymph and adult mite after 14 days approximately. Its symptoms develop as a result of hypersensitivity to mites and their product. However the second infestation, the symptoms can earlier (after 1-2 weeks) due to immune memory. (Ständer \& Ständer, 2021)

Patients diagnosed with positive scabies had the type of lesions papules 13 (38.23 percent), burrow, vesicles, nodules and crusted each 6 (17.65 percent) and erythema 9 (26.70 percent) patients. Patients which diagnosed as negative scabies 
were had type of lesions excoriation 5 (14.71 percent), crusted 1 (2.94 percent), suppuration 2 (5.88 percent) erythema 7 (20.59 percent) pustule 5 (14.71 percent) abscess 4 (11.76 percent) patients. Each patient had multiple types of lesions-itch and skin lesions, most commonly small scattered papules, often with excoriation. Burrow may be found but not in all cases, as a pattern of symptoms and signs is known as classical scabies. Another type of lesions also obtained by (Walter et al., 2011) is papules, nodules, vesicles, crusted papules, and superinfection.

Crusted 'Norwegian' scabies in patients characterized by plaques and extensive scales and crust containing millions of mites associated with the erythema. This form is highly infectious, is associated with mortality occurs more frequently in immunosuppressed individuals. Complication scabies caused by secondary or superinfection of bacteria may lead to multiple types of lesions such as vesicles, pustules, suppuration, and abscess. (WHO, 2019)

Table 3. Cross-tabulation of Clinical Assessment and Adhesive Tape Microscopic for Scabies Diagnostic

\begin{tabular}{cccc}
\hline & \multicolumn{2}{c}{ Adhesive Tape Microscopic } & \\
\cline { 2 - 3 } Clinical & Positive & Negative & Total \\
Assessment & $\mathrm{N}(\%)$ & $\mathrm{N}(\%)$ & \\
\hline Positive & 13 & 1 & \\
$\mathrm{~N}(\%)$ & $(38.24)$ & $(2.93)$ & $(41.17)$ \\
Negative & 18 & 2 & 20 \\
$\mathrm{~N}(\%)$ & $(52.94)$ & $(5.88)$ & $(58.82)$ \\
\hline Total & 31 & 3 & 34 \\
$\mathrm{~N}(\%)$ & $(91.19)$ & $(8.81)$ & $(100.00)$ \\
\hline
\end{tabular}

Table 3 shows a cross-tabulation of result clinical assessment and adhesive tape microscopic for scabies diagnostic. The number of positive scabies by clinical assessment was 14 (41.18 percent) and 20 (58.82 percent) negative scabies. The adhesive-tape microscopic examination resulted in 31 (91.18 percent) positive scabies and 3 (8.82 percent) negative scabies. The difference was significantly based on Cohen's kappa $(\mathrm{k}=0.024)$ shown in Table 4.

Table 4. Cohen's Kappa of Clinical Assessment and Adhesive Tape Microscopic for Scabies Diagnostic

\begin{tabular}{lrrrc}
\hline & Value & $\begin{array}{c}\text { Asymp. } \\
\text { Std.Error }\end{array}$ & $\begin{array}{c}\text { Approximate } \\
\mathrm{T}^{\mathrm{b}}\end{array}$ & $\begin{array}{c}\text { Approximate } \\
\text { Significance }\end{array}$ \\
\hline $\begin{array}{l}\text { Measure of } \\
\text { Agreement }\end{array}$ Kappa & .024 & .081 & .289 & .773 \\
\hline$\quad$ N of Valid Case & 34 & & & \\
\hline
\end{tabular}


Table 5. Interpretation of Clinical Assessment and Adhesive Tape Microscopic for Scabies Diagnostic

\begin{tabular}{|c|c|c|c|}
\hline $\begin{array}{c}\text { Clinical } \\
\text { Assessment }\end{array}$ & $\begin{array}{l}\text { Adhesive Tape } \\
\text { Microscopic }\end{array}$ & $\mathrm{N}(\%)$ & Interpretation \\
\hline Positive & Positive & $13(38.24)$ & $\begin{array}{l}\text { TP Clinical Assessment/ } \\
\text { TP Adhesive-Tape }\end{array}$ \\
\hline Negative & Positive & 18 (52.94) & $\begin{array}{l}\text { FN Clinical Assessment/ } \\
\text { FP Adhesive-Tape }\end{array}$ \\
\hline Negative & Negative & $2(5.88)$ & $\begin{array}{l}\text { TN Clinical Assessment/ } \\
\text { TN Adhesive-Tape }\end{array}$ \\
\hline Positive & Negative & $1(2.93)$ & $\begin{array}{l}\text { FP Clinical Assessment/ } \\
\text { FN Adhesive-Tape }\end{array}$ \\
\hline
\end{tabular}

Abbreviations: FN, false-negative; FP, false-positive; TN, true-negative; TP, true-positive

The diagnostic parameter's value of clinical assessment and adhesive tape microscopic for scabies diagnostic shown in Table 5 and Table 6. In total, 13 (38.24 percent) of 34 patients were diagnosed by both methods as positive scabies, truepositive (TP), and 2 (5.88 percent) as negative scabies true-negative (TN). The number of patients positive by clinical assessment only was 1 (2.93 percent) as falsepositive (FP), and the number of patients negative by clinical assessment only was 18 (22.9 percent) as false-negative (FN).

Table 6. Diagnostic Parameters Value of Clinical Assessment with Adhesive Tape Microscopic for Scabies Diagnostic

\begin{tabular}{lc}
\hline \multicolumn{1}{c}{ Diagnostic Parameters } & Value \\
\hline Sensitivity (TP/TP+FN) & $41.93 \%$ \\
Specificity (TN/TN+FP) & $66.67 \%$ \\
Negative Predictive Value (TN/TN+FN) & $10.00 \%$ \\
Positive Predictive Value (TP/TP+FP) & $92.85 \%$ \\
Mean Accuracy (TP+TN)/(TP+TN+FP+FN) & $41.11 \%$ \\
\hline
\end{tabular}

Abbreviations: FN, false-negative; FP, false-positive; TN, truenegative; TP, true-positive

Table 6 shows diagnostic parameters: sensitivity, specificity, positive predictive value, negative predictive value, and accuracy. In definition, the clinical sensitivity assessment of 41.93 percent was lower than adhesive tape microscopic, its specificity 66.67 percent, negative predictive value 10.00 percent, and positive predictive value was 92.85 percent. The accuracy of clinical assessment against adhesive tape was only 44,11 percent.

Although the positive predictive value clinical assessment was high (92.85 percent), its sensitivity ( 41.83 percent) and accuracy ( 44,11 percent) were lower than adhesive tape. It is similar to the result of the study by (Osti et al.,2019); amongst the 171 students diagnosed by clinical assessment, the prevalence of scabies and impetigo according to standard was 45 percent and 55 percent, respectively. The nonexpert health worker's sensitivity compared to the reference standard was 55.3 percent for scabies. 


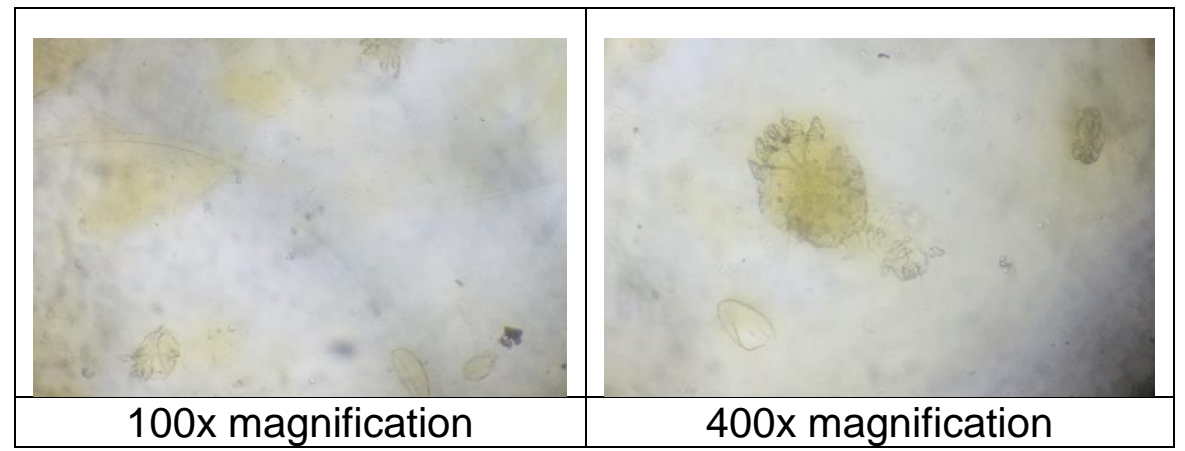

Figure 1. Results of Adhesive Tape Laboratory Microscopic Examination with Egg, Immature and Adult of Sarcoptes scabiei Presence at 40x and 100x Magnification

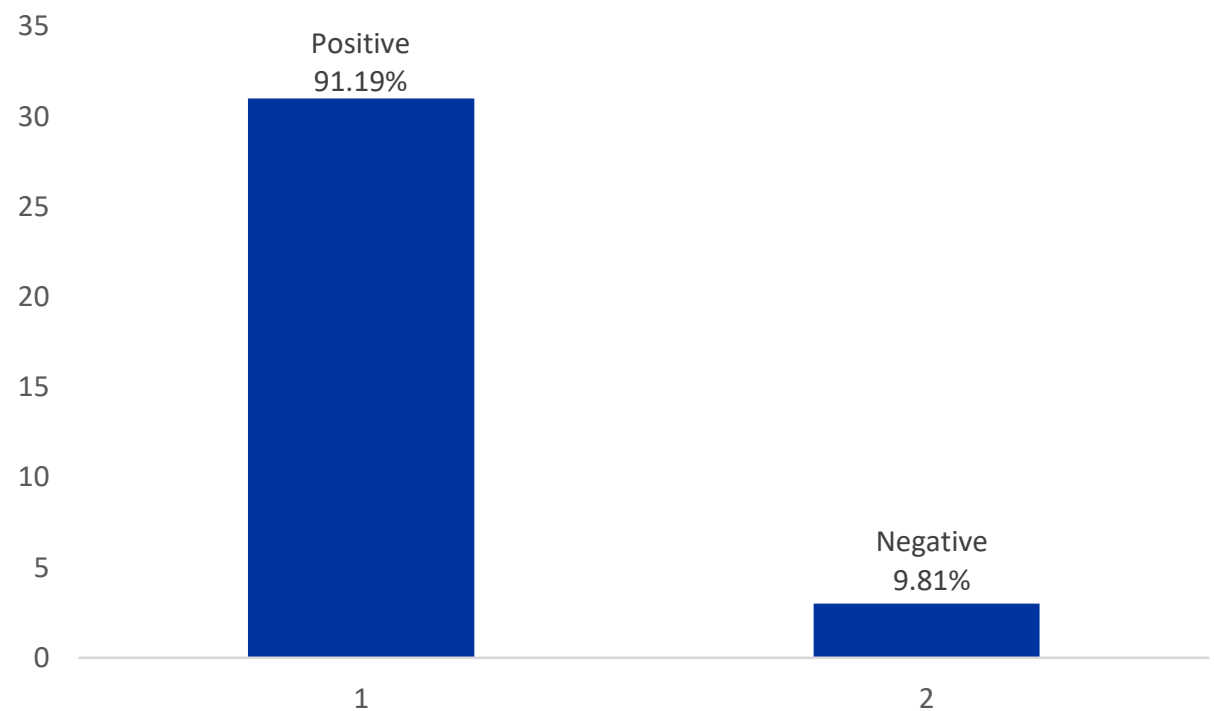

Figure 2. Results of Adhesive Tape Microscopic Examination for Scabies Diagnostic

Figure 1. shows the presence of eggs, immature and adult Sarcoptes scabiei mite in scanning light microscopic adhesive-tape slide 100x and 400x magnification reported as positive scabies. Figure 2 shows the result of adhesive tape microscopic examination for scabies diagnostic which 31 (91.19 percent) patients were positive and 3 (8.81 percent) patients negative. The diagnosis of scabies through optical/light microscopy to identified egg, immature and adult mite or scybala (feces) in adhesive tape preparation taken from representative lesional skin.

The previous systemic review by (Leung \& Miller 2011) from 18 studies shows that is none of the studies reviewed evaluated the accuracy of history and clinical assessment of pruritic dermatosis to diagnosed scabies. The other systematic review from 71 studies worldwide of scabies diagnostic by (M. J. Thompson, D. Engelman, K. Gholam, L. C. Fuller, 2017) shows 56 percent diagnosis of scabies were used clinical assessment, and 63 percent used parasitology testing, which prefers used in clinic base than in fields studies.

This study results from the resulting study by (Walker et al., 2020), which diagnosed by clinical assessment of non-expert examiner with training used diagnostic criteria of scabies by IACS. Its result shows the accuracy of non-expert examiner to detect typical scabies between 70-96 percent and sensitivity between 
69-83 percent. Its shows that clinical assessment following briefly training and proper guideline promising accuracy for scabies diagnostic.

The Consensus Criteria for diagnosing scabies as a proper guideline released by The International Alliance for the Control of Scabies (IACS) in 2020 include three levels of diagnostic certainty and eight subcategories. The three levels include confirmed scabies (level A) requires direct visualization of the mite or its products, clinical scabies (level B), and suspected scabies (level C) rely on clinical assessment of signs and symptoms. The consensus criteria may provide greater consistency and standardization and could be implemented by selecting the appropriate diagnostic levels and subcategories (Engelman et al., 2020).

Positive scabies based on the result of the adhesive-tape microscopic examination was 31 (91.18 percent) higher than clinical assessment. Its value higher than the previous study by Walter et al., 2011, in which the negative predictive value was high (0.85:95 percent $\mathrm{Cl}, 0.75-0.91$ ). Base on the study by (Zorbozan et al., 2020), the adhesive tape test has high specificity in diagnosing scabies by seeing mite and other immature stage confirmation. However, its low sensitivity cannot exclude the possibility of scabies. The adhesive tape sticks all mite or egg and scybala on the upper layer of skin. Although repeating skin scratching loosened the upper layers of the epidermis, the stratum corneum residues with mites will be stick on the adhesive tape. The adhesive tape will also stick mites which temporarily migrating on the skin in an early infestation.

Scabies is a common parasitic skin disease that causes morbidity globally may lead to mortality caused by a secondary infection from impetigo to chronic kidney disease. Treating scabies is quite expensive and becomes more expensive if patients have severe scabies with secondary infection complications by bacteria. However, early diagnosing of scabies needs to prescribe treatment. (Trasia, 2021)

According to (Zorbozan et al., 2020) its impossible to diagnosed scabies by clinical assessment only because some scabies symptoms are similar to other diseases, such as pyoderma, atopic dermatitis, especially in children and in immunocompromised conditions. Scabies manifestation with a multi-spectrum of clinical signs and variable severities can negatively affect the clinical assessment. Scratching itch may lead to excoriation of skin and burrow as the cardinal sign will be masked by a secondary infection which different symptoms. Clinical assessment of scabies diagnostic need experienced clinicians. However, we need another method for the diagnosis of scabies (Estrada-Chávez et al., 2018).

On the other hand, the adhesive tape test is easy, low cost, and needs no expensive equipment, although secondary infection may reduce mite presence. It recommended adhesive tape laboratory microscopic for screening purposes. It is possible to diagnose scabies with the comprehensive proper clinical assessment with diagnosis guidelines from IACS and laboratory test, and mainly adhesive tape test highly recommended.

The limitation of this research is the lack of respondents. This study only compared the results between the two tests without comparing the standard gold test for scabies diagnostic.

\section{CONCLUSION}

The study concluded that the scabies diagnostic accuracy of clinical assessment is limited than adhesive tape. The adhesive tape test is easy, low cost, and needs no expensive equipment. However, it is recommended that adhesive tape 
laboratory microscopic for screening purposes. The appropriate comprehensive of both methods for scabies diagnostic is highly recommended.

\section{ACKNOWLEDGEMENT}

The author would like to thank all parties involved in this study.

\section{CONFLICT OF INTEREST}

The author declares that there is no conflict of interest regarding the publication of this paper.

\section{REFERENCES}

Audhah, N., Umniyat, S. R., \& Siswati, A. S. (2012). Scabies risk factor on students of Islamic boarding school (Study at Darul Hijrah Islamic Boarding School, Cindai Alus village, Martapura Subdistrict, Banjar District, South Kalimantan). Jurnal BUSKI Jurnal Epidemiologi Dan Penyakit Bersumber Binatang, 4(1), 14-22.

Engelman, D., Yoshizumi, J., Hay, R. J., Osti, M., Micali, G., Norton, S., Walton, S., Boralevi, F., Bernigaud, C., Bowen, A. C., Chang, A. Y., Chosidow, O., EstradaChavez, G., Feldmeier, H., Ishii, N., Lacarrubba, F., Mahé, A., Maurer, T., Mahdi, M. M. A., ... Fuller, L. C. (2020). The 2020 International Alliance for the Control of Scabies Consensus Criteria for the Diagnosis of Scabies. British Journal of Dermatology, 183(5), 808-820. https://doi.org/10.1111/bjd.18943

Estrada-Chávez, G., Estrada, R., Engelman, D., Molina, J., \& Chávez-López, G. (2018). Cushing syndrome due to inappropriate corticosteroid topical treatment of undiagnosed scabies. Tropical Medicine and Infectious Disease, 3(3). https://doi.org/10.3390/tropicalmed3030082

Katsumata, K., \& Katsumata, K. (2006). A simple method of detecting Sarcoptes scabiei var hominis mites among bedridden elderly patients suffering from severe scabies infestation using an adhesive tape. Internal Medicine, 45(14), 857-859. https://doi.org/10.2169/internalmedicine.45.1707

Leung, V., \& Miller, M. (2011). The 2010 CJIDMM Trainee Review Award Detection of scabies: A systematic review of diagnostic methods. Can J Infect Dis Med Microbiol, 22(4), 143-146.

M. J. Thompson, D. Engelman, K. Gholam, L. C. Fuller, A. C. S. (2017). Systematic review of the diagnosis of scabies in therapeutic trials. Clinical and Experimental Dermatology, 42(5), 481-487. https://doi.org/https://doi.org/10.1111/ced.13152

Muafidah, N., Santoso, I., \& Darmiah. (2017). Hubungan Personal Higiene dengan Kejadian Skabies pada Santri Pondok Pesantren Al Falah Putera Kecamatan Liang Anggang Tahun 2016. Journal of Health Science and Prevention, 1(1), 7-10.

Osti, M. H., Sokana, O., Gorae, C., Whitfeld, M. J., Steer, A. C., \& Engelman, D. (2019). The diagnosis of scabies by non-expert examiners: A study of diagnostic accuracy. PLoS neglected tropical diseases, 13(8), e0007635.

Ständer, S., \& Ständer, S. (2021). Itch in Scabies-What Do We Know? Frontiers in Medicine, 8(February), 1-6. https://doi.org/10.3389/fmed.2021.628392

Trasia, R. F. (2021). Scabies in Indonesia: Epidemiology and Prevention. Insights in Public Health Journal, 1(2), 30. https://doi.org/10.20884/1.iphj.2020.1.2.3071

Walker, S. L., Collinson, S., Timothy, J., Zayay, S., Kollie, K. K., Lebas, E., Halliday, K., Pullan, R., Fallah, M., \& Marks, M. (2020). A community-based validation of the international alliance for the control of scabies consensus criteria by expert 
and non-expert examiners in Liberia. PLoS Neglected Tropical Diseases, 14(10), 1-11. https://doi.org/10.1371/journal.pntd.0008717

Walter, B., Heukelbach, J., Fengler, G., Worth, C., Hengge, U., \& Feldmeier, H. (2011). Comparison of dermoscopy, skin scraping, and the adhesive tape test for the diagnosis of scabies in a resource-poor setting. Archives of Dermatology, 147(4), 468-473. https://doi.org/10.1001/archdermatol.2011.51

WHO. (2019). WHO Informal Consultation on a Framework for Scabies Control Meeting report (Issue February).

Zhang, W., Zhang, Y., Luo, L., Huang, W., Shen, X., Dong, X., Zeng, W., \& Lu, H. (2020). Trends in prevalence and incidence of scabies from 1990 to 2017: findings from the Global Burden of Disease study 2017. Emerging Microbes and Infections, 9(1), 813-816. https://doi.org/10.1080/22221751.2020.1754136

Zorbozan, O., Gerçeker Türk, B., Acar, A., Oraloğlu, G., Ünver, A., Töz, S., Ünal, İ., \& Turgay, N. (2020). Comparison of Skin Scraping and Standard Superficial Skin Biopsy in the Laboratory Diagnosis of Scabies. Turkiye Parazitolojii Dergisi, 44(3), 164-167. https://doi.org/10.4274/tpd.galenos.2020.6828 